\title{
Body mass index, waist-to-hip ratio, and body surface area in patients with acute ischaemic stroke in north-eastern Poland
}

\author{
Wskaźnik masy ciała, stosunek obwodu talii do obwodu bioder i wskaźnik otłuszczenia ciała \\ u pacjentów z udarem niedokrwiennym mózgu w północno-wschodniej Polsce
}

\author{
'Department of Neurology, Medical University of Bialystok, Białystok, Poland \\ ${ }^{2}$ Student Scientific Association in the Department of Neurology, Medical University of Bialystok, Białystok, Poland \\ ${ }^{3}$ Faculty of Economic Sciences, University of Warsaw, Warsaw, Poland \\ ${ }^{1}$ Klinika Neurologii, Uniwersytet Medyczny w Białymstoku, Białystok, Polska \\ ${ }^{2}$ Studenckie Koło Naukowe przy Klinice Neurologii, Uniwersytet Medyczny w Białymstoku, Białystok, Polska \\ ${ }^{3}$ Wydział Nauk Ekonomicznych, Uniwersytet Warszawski, Warszawa, Polska \\ Correspondence: Agata Czarnowska, Klinika Neurologii, Uniwersytecki Szpital Kliniczny w Białymstoku, ul. M. Skłodowskiej-Curie 24A, 15-276 Białystok, \\ tel.: +48 8574683 26, e-mail: zajkowskaagata@gmail.com
}

\begin{abstract}
Aim of the study: The aim of our study was to analyse the obesity indicators [body mass index (BMI), waist-to-hip ratio (WHR), waist circumference (WC), and the less-known body adiposity index (BAI)] to assess their influence on the severity and short-term outcome in both females and males after ischaemic stroke admitted over a period of 9 successive months to the Department of Neurology at the Medical University of Bialystok, Poland. Materials and methods: Based on the BMI, we divided the patients into the following groups: underweight, normal weight, overweight, and obese. The severity of stroke was evaluated by the National Institute of Health Stroke Scale (NIHSS). STATA 15 software (StataCorp, 2017) was used for statistical analysis. Results: The results demonstrated that there was no association between the BMI and changes in patient condition during hospitalisation in the stroke unit. The BAI had no clear correlation with the short-term outcome. However, a comparison of accuracy revealed that the BAI was a more precise indicator, and could better predict NIHSS improvement over treatment than the BMI. Among the analysed indicators, only the WC correlated with the difference between the NIHSS scores on admission and at hospital discharge. Conclusions: The BMI, used in clinical practice for decades, is far from a precise predictor of functional outcome after ischaemic stroke. This is the first study that takes into account the obesity indicator BAI in patients after acute ischaemic stroke. According to our results, in the future we should focus more attention on abdominal adiposity indicators such as the BAI or WC.
\end{abstract}

Keywords: stroke, obesity, body mass index (BMI), body adiposity index (BAI), waist circumference (WC)

Streszczenie Cel badania: Celem badania była analiza pomiarów antropometrycznych [wskaźnika masy ciała (body mass index, BMI), stosunku obwodu talii do bioder (waist-to-hip ratio, WHR), obwodu talii (waist circumference, WC) oraz mniej znanego wskaźnika otłuszczenia ciała (body adiposity index, BAI)] u pacjentów hospitalizowanych w ciągu kolejnych 9 miesięcy w Klinice Neurologii Uniwersytetu Medycznego w Białymstoku z powodu udaru niedokrwiennego mózgu. Poszukiwano korelacji między ciężkością udaru mózgu, rokowaniem krótkoterminowym a wymienionymi parametrami. Materiał i metody: Na podstawie BMI pacjenci zostali podzieleni na następujące grupy: osoby z niedowagą, prawidłową masą ciała, osoby z nadwagą oraz otyłe. Ciężkość udaru była oceniana według Skali Udaru Narodowego Instytutu Zdrowia (National Institute of Health Stroke Scale, NIHSS). Do obliczeń statystycznych wykorzystano program STATA 15 software (StataCorp, 2017). Wyniki: Na podstawie uzyskanych wyników nie zaobserwowano korelacji między ciężkością udaru niedokrwiennego mózgu a BMI. Z kolei BAI nie miało wpływu na rokowanie krótkookresowe. Jednak porównanie wskaźników BMI i BAI ujawniło, że BAI jest dokładniejszym narzędziem mogącym służyć do prognozowania przebiegu udaru mózgu. Spośród analizowanych wskaźników tylko WC korelowało z różnicą między NIHSS przy przyjęciu a NIHSS przy wypisie ze szpitala. Wnioski: BMI, stosowany w praktyce klinicznej od dziesięcioleci, nie jest idealnym wskaźnikiem mogącym służyć do prognozowania przebiegu udaru mózgu. 
Przedstawione badanie jako pierwsze uwzględnia wskaźnik otyłości BAI u pacjentów hospitalizowanych z powodu ostrego niedokrwienia ośrodkowego układu nerwowego. Uzyskane wyniki wskazują, że w przyszłych analizach pacjentów z udarem mózgu warto uwzględnić wskaźniki otyłości brzusznej, takie jak BAI i WC.

Słowa kluczowe: udar mózgu, otyłość, wskaźnik masy ciała (BMI), wskaźnik otłuszczenia ciała (BAI), wskaźnik obwodu talii (WC)

\section{INTRODUCTION AND OBJECTIVE}

A round 15 million people worldwide suffer from stroke each year, making it the second-highest cause of death (World Health Organization, 2018). The European population is aging, so there are more and more elderly patients at risk of stroke (Pastuszak et al., 2018). This is why primary prevention should be at the centre of our attention. However, to ensure effectiveness, it is necessary to find new, more precise prognostic indicators. One of the modifiable risk factors is obesity, and the association of obesity with ischaemic stroke has recently been studied (Andersen and Olsen, 2015; O'Donnell et al., 2010). Many of such studies suggest the presence of an "obesity paradox" in obese stroke survivors (Andersen and Olsen, 2015; Doehner et al., 2013; Kim et al., 2015; Ovbiagele et al., 2011; Vemmos et al., 2011). On the other hand, different indicators of obesity such as the body mass index (BMI) and the less popular waist-to-hip ratio (WHR), waist circumference (WC), or body adiposity index (BAI), can lead to differences in conclusions (Bembenek et al., 2018; Xu et al., 2014). The aim of our study was to analyse the aforementioned obesity indicators (BMI, WC, WHR, and the less-known BAI) in order to assess their influence on the severity and short-term outcome in both females and males after ischaemic stroke.

\section{MATERIALS AND METHODS}

We analysed patients with acute ischaemic stroke admitted over a period of 9 successive months of 2019 to the Department of Neurology at the Medical University of Bialystok, one of the largest stroke centres in the north-east of Poland. Data were collected prospectively, and included information about the patients' demographics (age, gender), presence of risk factors (hypertension, atrial fibrillation, dyslipidaemia, diabetes, present malignant tumours, ischaemic heart disease, smoking, and alcohol abuse), and anthropometric measurements (weight, height, waist and hip circumference, BMI, WHR, and BAI). The weight, height, waist and hip circumference were measured by medical students from the Student Scientific Association of the Department of Neurology during the patients' hospital stay, while they were supine. The lack of any measurements excluded the stroke patients from the statistics.

Based on the BMI, we divided the patients into the following groups: underweight (BMI less than $18.5 \mathrm{~kg} / \mathrm{m}^{2}$ ), normal weight $\left(B M I=18.5-24.9 \mathrm{~kg} / \mathrm{m}^{2}\right)$, overweight $\left(B M I=25-29.9 \mathrm{~kg} / \mathrm{m}^{2}\right)$, and obese $\left(B M I\right.$ over $\left.30 \mathrm{~kg} / \mathrm{m}^{2}\right)$. The BMI was calculated using the following formula (Churilla, 2018):

$$
\mathrm{BMI}=\mathrm{m} \text { (mass in kilograms)/h (height in meters) }
$$

A normal WHR was defined as less than or equal to 0.85 in women, and less than or equal to 1.0 in men. Proper waist circumference was defined as less than $80 \mathrm{~cm}$ in women, and less than $94 \mathrm{~cm}$ in men. The BAI (\%) is a less wellknown obesity indicator; its values depend on age and gender (Tabs. 1 and 2). It was calculated from the formula below (Jabłonowska-Lietz et al., 2017):

$$
\mathrm{BAI}=\left(100 \times \text { hip circumference }[\mathrm{m}] / \text { height }[\mathrm{m}]^{1.5}\right)-18
$$

Routine basic laboratory tests and brain imaging examinations (computed tomography, CT or, in selected cases, magnetic resonance imaging, MRI) were performed in every patient at admission. The diagnosis of stroke was based on the World Health Organization definition. The severity of stroke was evaluated by a neurologist according to the National Institute of Health Stroke Scale (NIHSS).

\begin{tabular}{|c|c|c|c|c|}
\hline Age [years] & Underweight & Normal & Overweight & Obese \\
\hline $20-39$ & Less than 21\% & $21-32.9 \%$ & $33-38.9 \%$ & More than $39 \%$ \\
\hline $40-59$ & Less than 23\% & $23-34.9 \%$ & $35-40.9 \%$ & More than $41 \%$ \\
\hline $60-79$ & Less than 25\% & $25-37.9 \%$ & $38-42.9 \%$ & More than $43 \%$ \\
\hline
\end{tabular}

Tab. 1. BAI classification for women

\begin{tabular}{|c|c|c|c|c|}
\hline Age [years] & Underweight & Normal & Overweight & Obese \\
\hline $20-39$ & Less than $8 \%$ & $8-20.9 \%$ & $21-25.9 \%$ & More than $26 \%$ \\
\hline $40-59$ & Less than $11 \%$ & $11-22.9 \%$ & $23-28.9 \%$ & More than $29 \%$ \\
\hline $60-79$ & Less than $13 \%$ & $13-24.9 \%$ & $25-30.9 \%$ & More than $31 \%$ \\
\hline
\end{tabular}




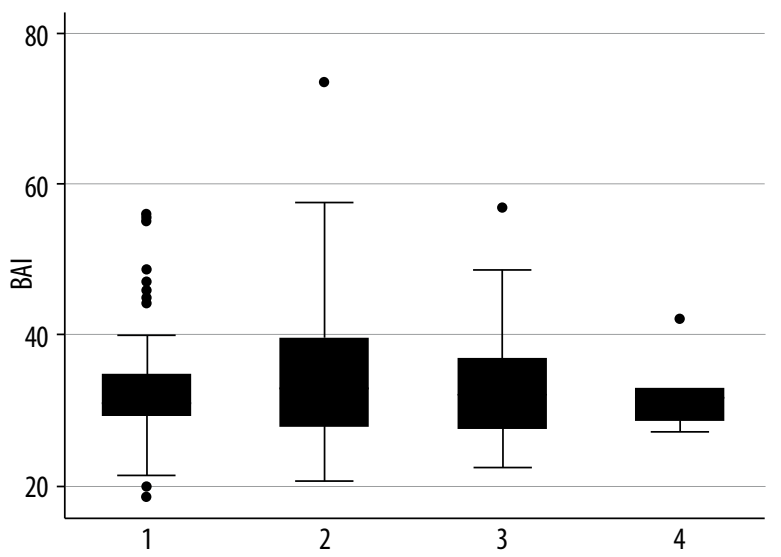

Fig. 1. Distribution of the BAI by the NIHSS categories: $I($ NIHSS $=0-3), I I(N I H S S=4-8), I I I(N I H S S=9-16)$, IV $($ NIHSS $\geq 16)$

We divided the patients into four groups: I (NIHSS $=0-3$ ), II (NIHSS $=4-8)$, III (NIHSS $=9-16)$, IV (NIHSS $\geq 16$ ).

STATA 15 software (StataCorp, 2017) was used for statistical analysis. The participants' characteristics were analysed descriptively, and for the analysis of collected data, we used Pearson correlation, $t$-test, linear regression, and logistic regression. The studies were approved by the Ethics Committee of the Medical University of Bialystok, Poland. The study was funded by the Medical University of Bialystok.

\section{RESULTS}

The analysed data consisted of 119 patients (53 females and 66 males) admitted with acute ischaemic stroke. The mean age of the population was 70.61 (standard deviation, $S D=11.90$, range 31-94 years), 73.43 for females $(S D=12.75$, range $31-90)$, and 68.34 for males $(S D=10.73$, range 44-94). For 93 patients, it was their first episode of stroke, and for 24 patients it was their second or further episode. For the whole group, we evaluated the NIHSS scores on admission and by hospital discharge (mean time of hospitalisation 10 days, range 7-29 days). Most of the patients presented with mild symptoms of stroke - there were $61 \mathrm{pa}$ tients with the lowest score, NIHSS I (0-3), and 41 patients were classified in the $2^{\text {nd }}$ group, NIHSS II (4-8). A total of 15 patients were included in the $3^{\text {rd }}$ group, NIHSS III (9-16). Finally, just 2 patients were deeply affected by stroke (NIHSS $>16$ ), and in another 2 patients the condition was fatal. The risk factors presented by the analysed group are given in Tabs. 3 and 4 .

We observed that the only factor significantly negatively correlated with the difference in NIHSS scores over treatment was the WC (Pearson correlation also showed that for the BAI $\rho=-0.2321, p<0.05)$ which suggests a greater improvement in neurological status in slimmer patients. Nevertheless, it does not have reliable prognostic properties. While the sensitivity of our models was reasonable, the specificity was far from satisfactory. We found no

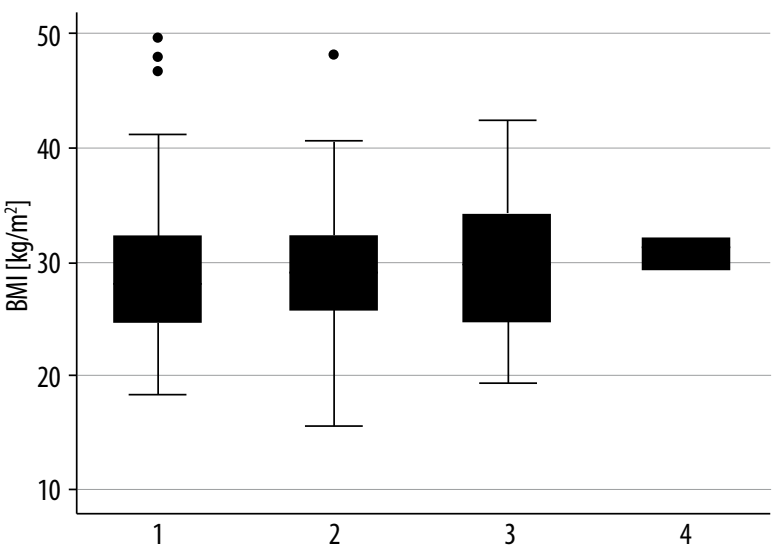

Fig. 2. Distribution of the BMI by the NIHSS categories: $I($ NIHSS $=0-3), I I($ NIHSS $=4-8), I I I($ NIHSS = 9-16), IV $($ NIHSS $\geq 16)$

statistically significant correlation between the NIHSS score on admission and the BMI $(p=0.509)$, BAI $(p=0.506)$, WHR $(p=0.577)$, and body mass $(p=0.489)$. The NIHSS score at discharge was not correlated significantly with the BMI $(p=0.778)$, BAI $(p=0.332)$, WHR $(p=0.502)$ or body mass $(p=0.832)$.

In terms of the severity of stroke measured with the NIHSS score, we found a significant correlation only with age the higher the patients' age, the higher the NIHSS score on admission $(\rho=0.1868, p<0.05)$.

In line with the results reported in the literature, using Pearson correlation, we have shown that the BMI and BAI correlate significantly with each other $(\rho=0.6611, p<0.05)$ (Geliebter et al., 2013). Moreover, the WC correlates significantly with all other indicators: the BMI $(\rho=0.8236$, $p<0.05)$, BAI $(\rho=0.5304, p<0.05)$, and WHR $(\rho=0.5071$, $p<0.05)$. Overweight patients had hypertension more frequently $(p<0.05)$. On the other hand, smokers had lower BMI and BAI scores $(p<0.05)$ than non-smokers, and problem drinkers had lower BAI values than patients who did not overuse alcohol $(p<0.05)$.

\section{Comparison of BMI and BAI}

Analysing the distribution of the BAI and BMI indicators by the NIHSS categories, in NIHSS I (0-3), there are more outliers on the BAI graph. Also, we can observe a greater variance in NIHSS II (4-8) in the BAI graph. For all NIHSS groups, we observe a greater dispersion of the BMI values. Nevertheless, these are not statistically significant.

The ROC (receiver operating characteristic) curve confirms the poor value of the BMI in predicting the severity of stroke expressed by the NIHSS score - it cuts the reference line, which means it is inferior to a simple coin toss. The BAI line is almost always above the BMI line, and furthermore it is always above the 45-degree line, which suggests it might be used as a predictor of whether the NIHSS score will drop over the course of treatment. It can come 


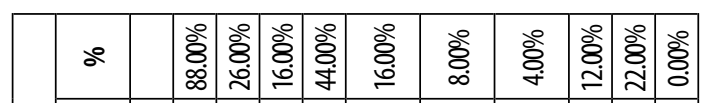

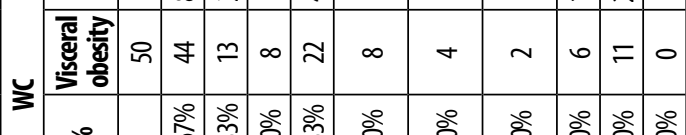

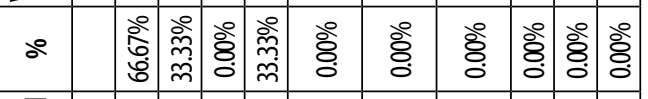
$\ln \cdots \cdots \cdots$

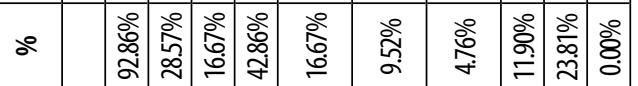

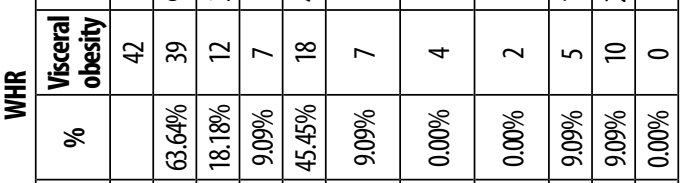
$\overline{1}=\sim \sim \cdots \cdots \cdots$

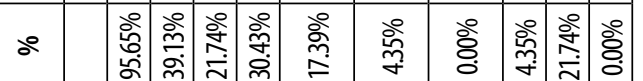

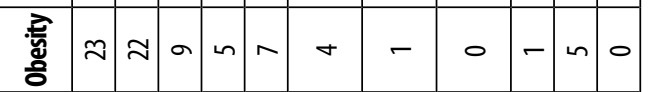
ஃ

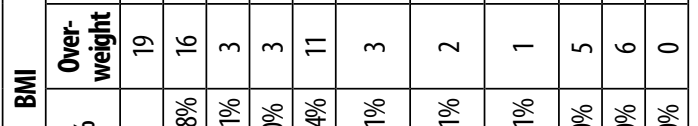
ஃ

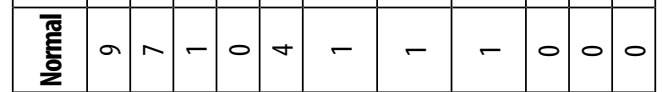

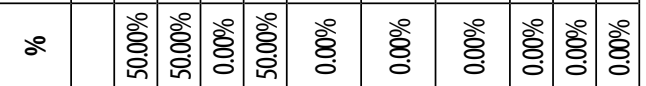

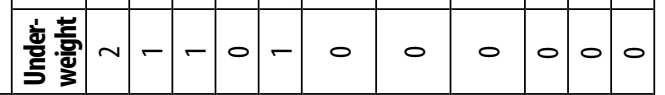

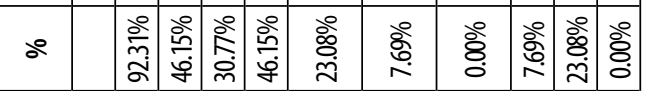
喜 $m \simeq 0+0 m-0-m 0$

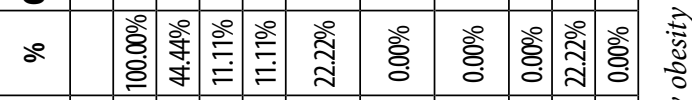

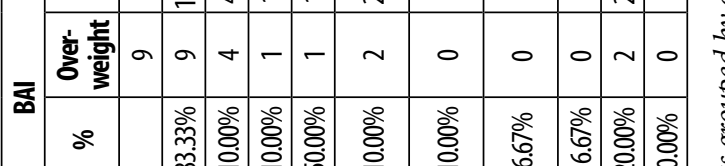

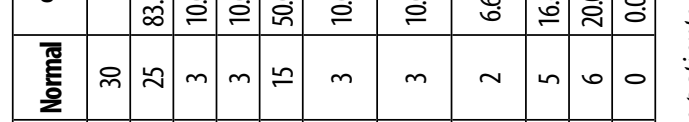

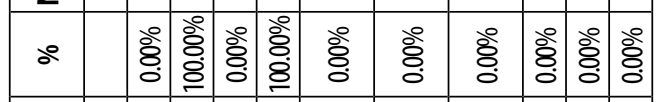

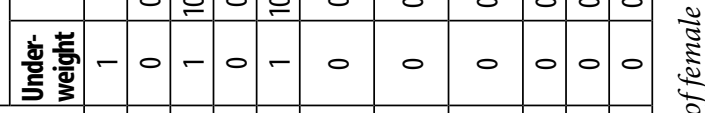

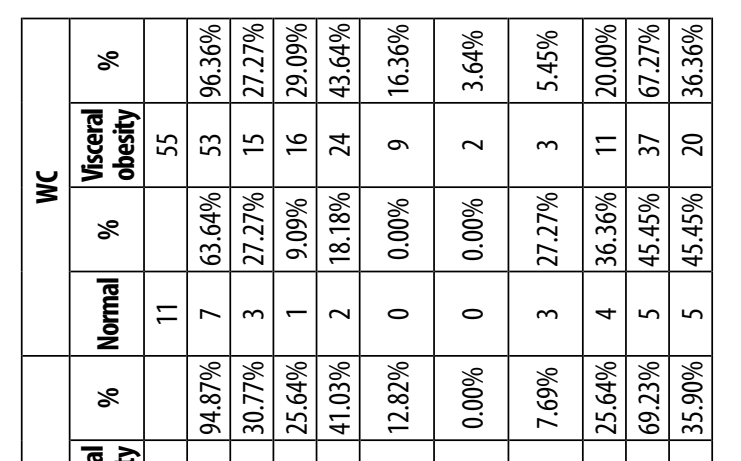

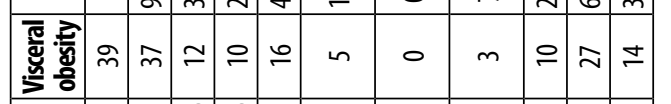

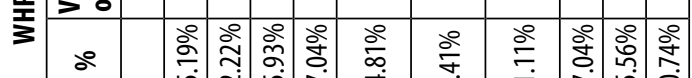
舟

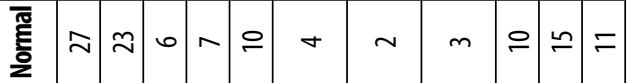

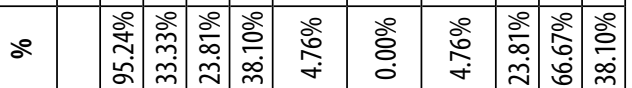

章 $\approx$ 人 n - $\infty-0-\infty \pm \infty$

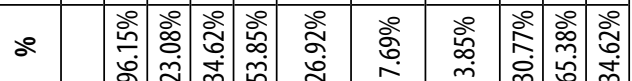

辛

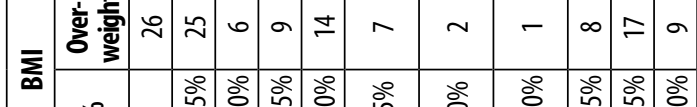

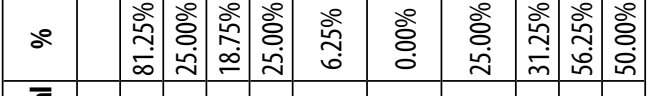
产 ஃ

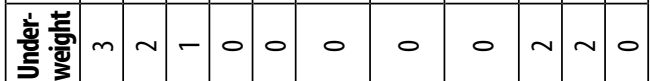
×

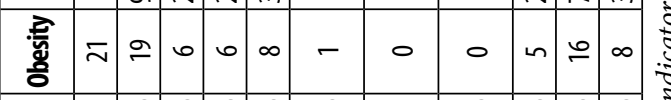

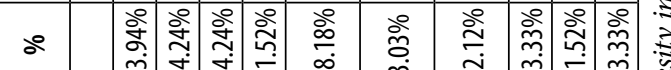

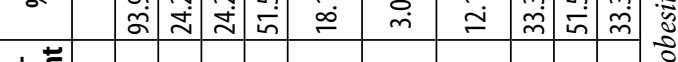
㐫

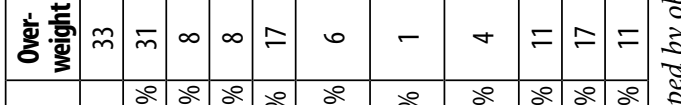

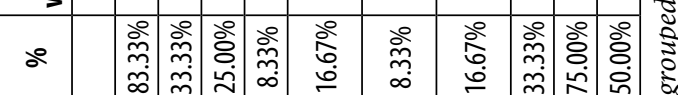

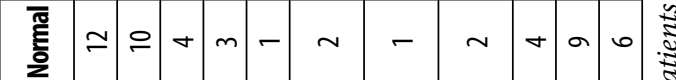
ஃ

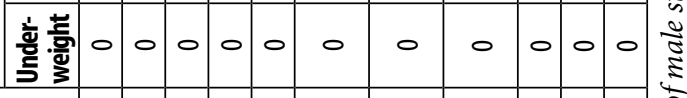

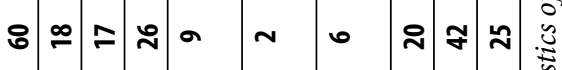

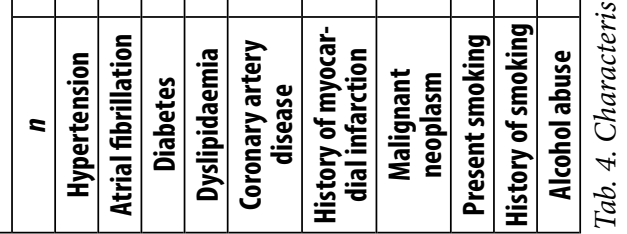




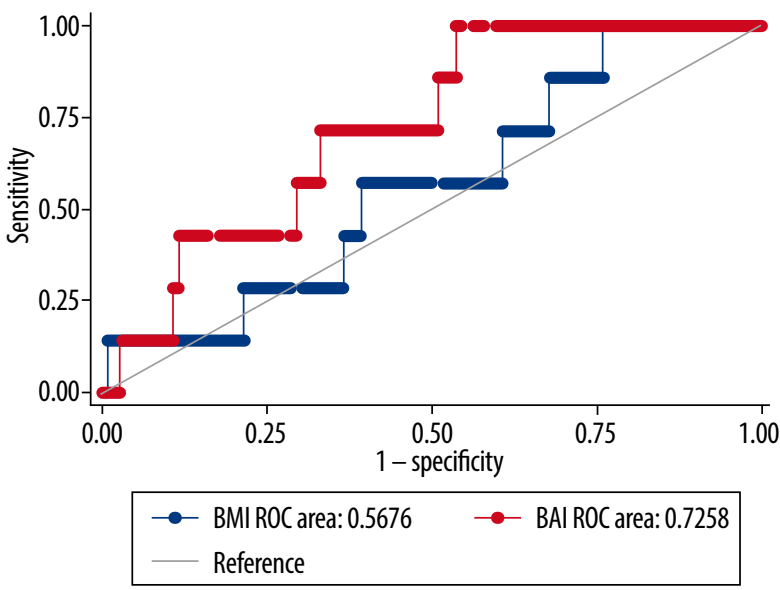

Fig. 3. The ROC curve describing the predictive value of the BAI (marked in red) and the BMI (marked in blue) in relation to the severity of stroke determined by the NIHSS score. The BAI line is almost always above the BMI line, and always above the 45-degree line

partially from greater dispersion on the display of the distribution of the BMI by NIHSS categories (Figs. 1-3).

\section{DISCUSSION}

The present study is the first to analyse the prognostic value of a new obesity indicator (BAI) in the assessment of severity and short-term outcome in patients after acute ischaemic stroke. Furthermore, the BAI has not previously been compared with the commonly used BMI indicator in groups of patients admitted with incidents of ischaemic stroke. To the best of our knowledge, there is no study concerning the BAI in neurological patients, although this measure is already widely studied by researchers from the cardiovascular disease field as an alternative to the BMI. According to a study by Zhang et al. (2014), the BAI strongly correlates with the PBF (\% body fat) when women and men are pooled together. The effect is not present when the groups of patients are sex-stratified (Zhang et al., 2014). Nevertheless, as the BMI is more convenient to use in everyday clinical practice, the BAI could be taken into account as an alternative to the BMI in severely affected, bedridden stroke patients. A study from New Delhi by Gupta and Kapoor (2014) suggests that the BAI can be used as an additional marker for screening the population, as it has certain advantages over the BMI, one being that the sensitivity and specificity of the BAI to predict hypertension was superior. The results demonstrate that there is no association between the BMI and changes in patient condition during hospitalisation in the stroke unit. Also, the BAI has no clear correlation with patients' short-term outcome. However, a comparison of BMI and BAI accuracy reveals that the BAI is a more precise indicator and could better predict NIHSS improvement over treatment than the BMI. Among the analysed indicators, only the WC correlates with the difference between the NIHSS scores on admission and at hospital discharge.
Our study is in line with the results presented by Bembenek et al. (2018), in which the BMI had the weakest relationship with short-term outcome among the investigated indicators. It must be pointed out that the BMI, used in clinical practice for decades, is far from a precise predictor of functional outcome after ischaemic stroke (Razinia et al., 2007). From this point of view, we should focus more attention on abdominal adiposity indicators.

According to our results, the WC provides the highest accuracy. A similar conclusion was reached in a study conducted in Warsaw, which highlights that the WC is sex-specific, and more relevant in groups of women (Bembenek et al., 2018). It is worth mentioning that some authors have suggested that the WC is superior to the BMI in describing visceral adipose tissue distribution (Jia et al., 2003). Since visceral obesity is a well-established risk factor for stroke, a wider use of the WC should be brought into consideration. According to our study, the WC correlates with the difference in the NIHSS scores on admission and at discharge; however, it could not be used as a predictive value of stroke severity expressed by NIHSS, as it does not have reliable prognostic properties. Nevertheless, more studies should be conducted on the subject, especially considering the fact that the WC is easier to obtain and measure than the BMI in stroke patients, many of whom are bedridden. It is interesting to note that our results show no correlation between stroke severity and in-hospital outcome and the WHR. In a study by Bembenek et al. (2018), high WHR values were associated with an increased risk of death or dependency at discharge. The INTERSTROKE study showed that population-attributable risks for the WHR and stroke varied in different regions of the world. In the same study, the WHR was associated with a larger odds ratio in women than in men (O'Donnell et al., 2016).

The BAI seemed to be a promising predictive value of stroke severity and short-term outcome. Unfortunately, our study shows no strong evidence of the BAI being superior to the BMI in this regard. However, since our study's main limitation is the relatively small group of patients coming from one medical facility, it is possible that the correlation of the BAI with stroke severity and short-term outcome could be a hopeful direction for researchers who have access to data from different hospitals. In further studies, we would like to expand the topic of adipose tissue as an endocrine organ, and explore the role of adipokines in chronic inflammation in relation to patients with ischaemic stroke (Mancuso, 2016). The correlation between the BAI, inflammatory parameters and stroke outcome might yield interesting insights.

\section{CONCLUSIONS}

This is the first Polish study that takes into account the obesity indicator BAI in patients after acute ischaemic stroke. The comparison of BMI and BAI accuracy revealed that the BAI is likely to be a more precise indicator of outcome after stroke than the BMI. However, this is only 
a preliminary analysis, so it is difficult to explain our results without further confirmatory studies and, in particular, prospective cohort studies on large, diverse populations, which should be carried out in the future. It seems that including the BAI in the future long-term research on stroke outcome is worth considering.

\section{Conflict of interest}

Ahe authors declare that there is no conflict of interest.

\section{References}

Andersen KK, Olsen TS: The obesity paradox in stroke: lower mortality and lower risk of readmission for recurrent stroke in obese stroke patients. Int J Stroke 2015; 10: 99-104.

Bembenek JP, Karlinski M, Niewada $\mathrm{M}$ et al.: Measurement of nutritional status using body mass index, waist-to-hip ratio, and waist circumference to predict treatment outcome in females and males with acute first-ever ischemic stroke. J Stroke Cerebrovasc Dis 2018; 27: 132-139.

Churilla JR: Anthropometrics and allometry: beyond body mass index. Metab Syndr Relat Disord 2018; 16: 159.

Doehner W, Schenkel J, Anker SD et al.: Overweight and obesity are associated with improved survival, functional outcome, and stroke recurrence after acute stroke or transient ischaemic attack: observations from the TEMPiS trial. Eur Heart J 2013; 34: 268-277.

Geliebter A, Atalayer D, Flancbaum L et al.: Comparison of body adiposity index (BAI) and bmi with estimations of \% body fat in clinically severe obese women. Obesity (Silver Spring) 2013; 21: 493-498.

Gupta S, Kapoor S: Body adiposity index: its relevance and validity in assessing body fatness of adults. ISRN Obes 2014; 2014: 243294.

Jabłonowska-Lietz B, Wrzosek M, Włodarczyk M et al.: New indexes of body fat distribution, visceral adiposity index, body adiposity index, waist-to-height ratio, and metabolic disturbances in the obese. Kardiol Pol 2017; 75: 1185-1191.
Jia WP, Lu JX, Xiang KS et al.: Prediction of abdominal visceral obesity from body mass index, waist circumference and waist-hip ratio in Chinese adults: receiver operating characteristic curves analysis. Biomed Environ Sci 2003; 16: 206-211.

Kim Y, Kim CK, Jung S et al.: Obesity-stroke paradox and initial neurological severity. J Neurol Neurosurg Psychiatry 2015; 86: 743-747.

Mancuso P: The role of adipokines in chronic inflammation. Immunotargets Ther 2016; 5: 47-56.

O'Donnell MJ, Chin SL, Rangarajan S et al.; INTERSTROKE investigators: Global and regional effects of potentially modifiable risk factors associated with acute stroke in 32 countries (INTERSTROKE): a case-control study. Lancet 2016; 388: 761-775.

O’Donnell MJ, Xavier D, Liu L et al.: Risk factors for ischaemic and intracerebral haemorrhagic stroke in 22 countries (the INTERSTROKE study): a case-control study. Lancet 2010; 376: 112-123.

Ovbiagele B, Bath PM, Cotton D et al.: Obesity and recurrent vascular risk after a recent ischemic stroke. Stroke 2011; 42: 3397-3402.

Pastuszak Ż, Koźniewska E, Stępień A et al.: Importance rating of risk factors of ischemic stroke in patients over 85 years old in the Polish population. Neurol Neurochir Pol 2018; 52: 88-93.

Razinia T, Saver JL, Liebeskind DS et al.: Body mass index and hospital discharge outcomes after ischemic stroke. Arch Neurol 2007; 64: 388-391.

Vemmos K, Ntaios G, Spengos K et al.: Association between obesity and mortality after acute first-ever stroke: the obesity-stroke paradox. Stroke 2011; 42: 30-36.

World Health Organization: Global Health Estimates 2016: Disease burden by Cause, Age, Sex, by Country and by Region, 2000-2016. World Health Organization, Geneva 2018.

$\mathrm{Xu}$ J, Xu T, Bu X et al.: The predictive value of waist-to-height ratio for ischemic stroke in a population-based prospective cohort study among Mongolian men in China. PLoS One 2014; 9: e110245.

Zhang ZQ, Liu YH, Xu Y et al.: The validity of the body adiposity index in predicting percentage body fat and cardiovascular risk factors among Chinese. Clin Endocrinol (Oxf) 2014; 81: 356-362. 